\title{
Columbus's Name in THE SPACE OF AMERICAN COLLECTIVE MEMORY: FROM CONSECRATION TO DESECRATION
}

\author{
Luisa Caiazzo \\ University of Basilicata, Italy
}

\begin{abstract}
Christopher Columbus used to be represented as an intrepid explorer who, by discovering America, marked the beginning of the modern age. Recently, the sacrality associated with his name has been challenged as a result of the increasing emphasis laid on the Native Americans' perspective, whereby Columbus, once deified, has recently often been vilified.

This paper focuses on the role Columbus's name has played in the space of American collective memory with an interest in Columbus Day, a national holiday since 1937, which in the last twenty-five years has been renamed as Indigenous People's Day in many cities across the United States, drawing a scenario where the holiday name is shaping different versions of the past.
\end{abstract}

Keywords: consecration, desecration, public holiday, memory, identity.

\section{Introduction}

During the five hundred and twenty-five years since Columbus's epochal arrival on American shores in 1492, his name has taken on several meanings across time and space and has been associated with different notions of heritage. Not only has Christopher Columbus dramatically changed the course of history, but he himself, or rather his persona, has never been the same throughout history (Wilford 1991: 66). In other words, his name has provided a malleable and empty signifier, available to be filled with an amazing variety of signifieds - ranging from facts to interpretations and connotations - whereby he has been either deified or desecrated. With an interest in the social function of names, the focus of the present study is not the history of the man and his accomplishments or misdeeds, but his name and the role it has played in the public space of American collective memory along an ideal continuum from consecration to desecration.

Woven through names - be they names of places, monuments, museums (Azaryahu 1996, Armada 1998, Alderman 2008, Vuolteenaho and Berg 2009) - are ideas about what matters, who counts and whose views and interests should be foregrounded. It is through reconstructing rather than recording the past that societies try to meet what they see as their contemporary cultural and political needs, hence collective memories often stem from manipulating the past in order to create or mold the 
present. As Azaryahu (1996: 312) observes, "[c] ommemorations not only celebrate extraordinary moments of history, but are also instrumental in their reification." And names contribute to this reifying process in that they, like commemorative street names or names of "monuments and heritage museums, not only evince a particular version of history but are also participants in the ongoing cultural production of a shared past" (Azaryahu 1996: 312). The social function of memory actually lays the foundation of the traditions to be invented (Hobsbawm 1983), the commemorations to be enacted and the narratives to be promoted.

From this perspective, public holidays and their names along with the rituals enacted for commemorative purposes as well as the language displayed on such occasion may be associated with toponyms, memorials and monuments in terms of the social function they perform in shaping the space of collective memory. As Roach (1996: 3-4) effectively argues, a performance lends itself to be a substitute for something else that preexists it, in that it "stands in for an elusive entity that it is not but that it must vainly aspire both to embody and replace. Hence flourish the abiding yet vexed affinities between performance and memory, out of which blossom the most florid nostalgia for authenticity and origin”. By presenting annual occasions for the ritualized remembering, public holidays contribute to developing a sense of identity and belonging. Therefore, their primary purpose should be to create unity or what Benedict Anderson has called "imagined communities". However, the responses to public holiday celebrations not only reveal a process of collaboration, but also one of contestation, which may produce competing images, identities and communities.

Along with the oral and corporeal "environments of memory" (Roach 1996: 26), histories are sedimented both in actual places and in the space of memory with their related linguistic reverberations. Holiday names and the language used and displayed on such occasions instantiate current moods and, in doing so, are constitutive of the social process.

Drawing on critical approaches to the study of names (Azaryahu 1996, Alderman 2008, Vuolteenaho and Berg 2009), names in public space (Felecan and Bugheșiu 2013) and people's views on (re)naming (Caiazzo 2014, in press), this paper foregrounds the rhetorical power of Columbus's name in the public space of celebrative rituals such as the American federal holiday Columbus Day.

After briefly presenting the approach adopted, the paper unfolds along the two main lines of consecration and desecration. The section devoted to the former provides an outline of the paths that led to venerating Columbus's name, whereas the one tackling the latter focuses on the analysis of some illustrative examples collected from the signs displayed on Columbus Day in the last two years. The closing section offers some reflections on the embeddedness of names into the social fabric of collective memories.

\section{The language around Columbus as the discursive facet of social processes}

Within the strand of linguistic enquiry set up by Firth (1957), which stresses the social and functional dimension of language, this study has adopted an integrated 
approach. On the one hand, it draws on history and social sciences research and, on the other, on the Appraisal Framework proposed by Martin and White (2005).

Such a relation between discursive and non-discursive aspects of social life is described by David Harvey (1996) in terms of internalization of different "moments" of social life. As shown in Figure 1, six distinctive "moments to the social process" are defined, one of them being language/discourse that includes the wide range of resources on which we can draw to represent the world. What the framework aims to point out is that the social process flows simultaneously through all the moments, since each of them is constituted as an internal relation of the others. Although discourses internalize what occurs at other moments and at the same time "suffuse and saturate all other moments within the social process" (Harvey 1996: 80), it might be misleading to privilege discourse above other moments. As is further argued, making reference to Raymond Williams (1977), language is constitutive of the way human beings are, in that it is the living evidence of the continuing social process which both shapes and is shaped by individuals: "Nor [...] is this language simply a 'reflection' or 'expression' of 'material reality'. What we have, rather, is a grasping of this reality through language, which as practical consciousness is saturated by and saturates all social activity, including productive activity. [...] Language is the articulation of this active and changing experience, a dynamic and articulated social presence in the world" (Williams 1997: 37-8 quoted in Harvey 1996: 88).

\section{Discourse/language}

Power Beliefs/values/desires

Social relations Institutions/rituals

Material practices

Figure 1. "Moments" in a Cognitive Map of the Social Process (Harvey 1996: 78)

Along similar lines, the way the social process is "internalized" by words and the meanings associated with them in relation to both verbal and contextual environment does play a role in Martin and White's (2005) notion of appraisal, which is concerned with the lexicalization of evaluation and the ways of positioning in interpersonal communication. These are mapped out on three main areas - attitude, engagement and graduation - which deal with our feelings, our ways of positioning and the grading of our opinions respectively. This study takes into account attitude, the framework that "involves three semantic regions covering what is traditionally referred to as emotion, ethics and aesthetics" (Martin and White 2005: 42), and engagement, which deals with "sourcing attitudes and the play of voices around opinions in discourse" (Martin and White 2005: 35).

Given the focus of this chapter on how Columbus's name has been shaped by and has shaped collective memory, it is worth considering that, in flowing simultaneously 
through all the moments of the social process, language shares and at the same time is part of the changes around Columbus's name and the public holiday named after him. Taking into account the framework for communication produced by the space of public holidays and the language moment that internalizes such framework may therefore contribute to getting further insights into the ongoing narratives whereby Columbus's Day is being renamed as Indigenous People's Day.

\section{Paths to consecration}

Virtually ignored for a long time after the first landfall, towards the end of the eighteenth century, Columbus was adopted in the American pantheon of heroes in colonial and revolutionary America, as " $\mathrm{t}] \mathrm{he}$ colonists needed a tradition that bypassed Great Britain, and they needed a name that would bind them into a group" (Bushman 1992:3). Along with the newborn nation, Columbus was created as a historical and symbolic personage, which placed his name at the center of American mythmaking in many ways for a long time. Although already in 1697 Massachusetts Chief Justice Samuel Sewall had referred to the New World as Columbina (Schlereth 1992), meaning 'land of Columbus', it was in the years preceding and following the American Revolution that the name Columbia emerged as an icon for the young republic to the point that " $[\mathrm{w}]$ ithin fifteen years of the American Revolution, versions of Columbus's name graced the titles of some sixteen periodicals, eighteen books, and half-dozen scholarly societies" (Dennis 2002: 2011). In addition, to quote but a very few examples, King's College in New York was renamed Columbia College in 1784, Columbus and Columbia were a popular subject for American poetry, appearing among many other works in Philip Freneau's 1774 The Pictures of Columbus and Joel Barlow's 1787 The Vision of Columbus, reworked as The Columbiad in 1807. Also, the presence of Columbus's name is especially intriguing when associated with Tammany, a fictive Native American chieftain after whom the Society of Tammany was named.

Established in New York in 1789, it became the Society of Tammany or Columbian Order shortly afterwards, thus boasting two patrons, both Tammany, who represented the New World, and Columbus, who represented the Old World. From the very beginning, Columbus was a major feature of the society's activities: "[ $t]$ he 'Calendar of the Society, issued with the Public Constitution in 1970', specified 12 October, the anniversary of the discovery of America, as a day sacred to the memory of the society's second patron, Columbus" (Bushman 1992: 82). And later, in the 1790s, the Society sponsored the opera Tammany, or the Indian Chief by Mrs. Anne Julia Hatton, in which Columbus was somehow given a prominent role. In addition, John Pintard, one of the leaders of the Tammany Society, proposed a procession, an oration as well as a memorial monument to celebrate the third centenary of the discovery of America in 1792. Interestingly, in one of the toasts, probably written by Pintard himself, reference was even made to the United Columbian States (Bushman 1992: 83-85). The vigor and potency of Columbus's name is also exemplified by the first permanent monument to 
Columbus, erected as a private tribute by the French consul Charles François Adrien le Paulmier on his estate in Baltimore in 1792.

Almost slumbering throughout the nineteenth century, Columbus's name was awakened when it was needed again on the anniversary of the first landfall, this time as a symbol of achievement and progress at the Columbian World's Fair held in Chicago in 1893. Celebrating the New World around the theme of the American commercial and technological leadership,

$[t]$ he fair directors sought to present a positive meaning of America, one in which the nation stood as a commercial, technological, and cultural leader. The optimistic style was a positive face painted on the troubling social changes that were occurring at the end of the nineteenth century. Not only was the country experiencing massive immigration, but it was also undergoing the shift from an agricultural to an industrial society, massive urbanization and poverty, economic recession, and challenges from the progressive movement (Kubal 2008: 28).

Equally impressive was the celebration in New York that lasted five days to give a chance to participate to all the constituencies that desired to pay homage to the mariner. The event drew considerable attention with one million visitors coming on the final day, which testifies to pervasiveness of the Columbian legend at that time. Moreover, an imposing Columbian monument was set at the entrance of Central Park with a plaque that presents Columbus as a hero personifying the virtues of bravery, creativity resourcefulness and self-reliance, a gift from Italians and Americans of Italian descent. Also, a major theme of New York's celebrations was the importance of Columbus as a Catholic (Italian) leader (Bushman 1992: 175), a fact that contributed to shaping further meanings around Columbus's name, both religious and ethnic (Kubal 2008).

As immigration became a massive phenomenon, Columbus came to be seen as an ethnic founding father, the first immigrant, the first Italian-American at a time when the label of the immoral and inferior Catholic justified discrimination and violent action against Catholic immigrants. In response to these waves of nativism and antiCatholicism, the Knights of Columbus, an Irish Catholic organization was founded in New Haven, Connecticut, in 1882. The reasons for the choice of the name are summed up in the words of one the founders: "I suggested the name of the Columbian Order having in view the name of Columbus, the great Catholic discoverer of America whose name would be a token of strength as showing we Catholics were no aliens to this country, but were entitled to all rights and privileges due to such Discovery by one of our faith" (Dennis 2002b: 142). The Columbus symbol was therefore central to their goals of fostering assimilation, challenging Catholic defamation and fighting stereotypes. Columbus's name served as an uplifting symbol for these communities, who invoked Columbus to legitimize the right to their citizenship and religious faith.

On the same ground, the Knights of Columbus and various other Italian-American organizations began to lobby Congress for federal recognition of Columbus Day. In 1892, President Benjamin Harrison delivered a proclamation that made October 12 a 
general holiday for the people of the United States. However, because of the hostility directed at Italian immigrants, strong resistance arose to making Columbus Day a legal holiday. As reported by Kammen (1993: 242), "“a]s one newspaper editorial put it in 1903 , 'nobody needs a «day off» every year to think about CoLUMBUS and the discovery of America [...]. Nobody but our engaging friends of the Mafia would need all day in which to celebrate the feat of their compatriot." Hence, it was not until 1937 that it was declared an official national holiday by President Franklin Roosevelt and became a federal holiday about thirty years later, in 1971, as a result of the Uniform Monday Holiday Act, whereby Columbus Day was observed on the second Monday in October each year. Among other implications, as Dennis (2002b: 150) points out, "the erection of Columbus Day and its success as a public holiday - not only among certain ethnic communities but nationally, at least in urban areas - marked the political arrival and strength of ethnic Americans in the United States."

\section{Towards desecration}

The growing veneration that had marked the paths to consecration drawn so far was followed by a slumbering interest in Columbus until the quincentenary in 1992, when Native Americans, in essentially the same way as those who preceded them, found in Columbus, turned by now into an antihero, a means to establish their identity, challenging traditional ethnocentric narratives of American history, and a means "to assert their legitimate, prior place in America, past, present, and future" (Dennis 2002b: 120).

Although preliminary planning for a giant international celebration for the 500th anniversary of Christopher Columbus's landing started well in advance - as early as 1984 - and saw the involvement of the White House (a Christopher Columbus Quincentenary Jubilee Commission was appointed by the President of the United States at the time, Ronald Reagan), the Smithsonian Institution, the Library of Congress and other organizations, the Quincentenary turned out to be a defining moment for Columbus's hero worship. In 1992, Berkley was the first city in the United States to rename the holiday as Indigenous People's Day, a tangible shift in the discourse and practice of Columbus's name in the public space of American collective memory. Since then, growing numbers of counties and cities throughout the United States have opted to celebrate Indigenous People's Day or Native American Day rather than Columbus Day.

Such a shift did not take place without troubles, as shown, among others, by the following headline from the Los Angeles Times of October 12, 1992: "Protesters Stop Mock Landing of Columbus: Boat is turned away in San Francisco. Egg-throwing demonstrators disrupt parade; 40 arrested". The article reported that a group of about 4,000 protesters prevented the re-enactment of Columbus's landing that was scheduled as part of the quincentennial Columbus Day celebration so that the boat bearing "Columbus" had to turn and speed away. Erasing the performance was symbolically meant to erase that historical narrative and paved the way to refashion that history. 


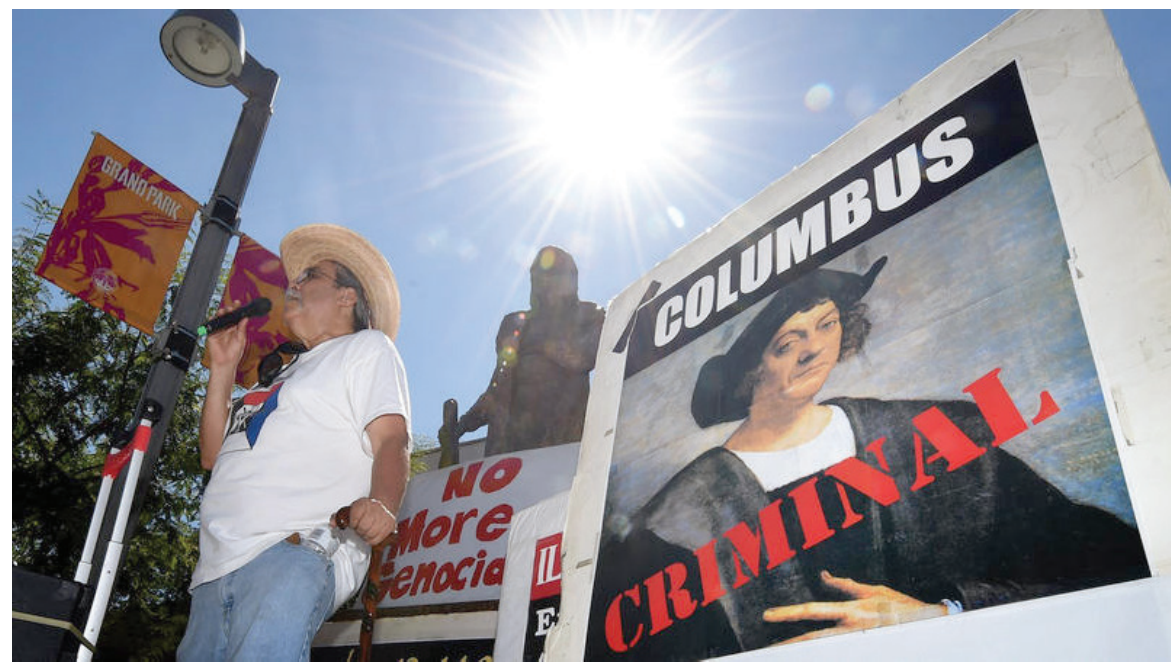

Figure 2. Olin Tezcatlipoca from the Mexica Movement speaks to demonstrators in front of a statue of Christopher Columbus in Los Angeles' Grand Park (Los Angeles Times, October 12, 2015)

Today, after twenty-five years, the holiday and its related parades keep being controversial, as demonstrated by the latest celebrations of Columbus Day this year (2017): "Columbus Day Has Drawn Protests Almost From Day 1" (New York Times, October 9,2017). Moreover, the signs displayed during some of the counterdemonstrations testify, once again, to the flexibility of Columbus's name, a "symbol for expressing changing national identities - first a British identity that excluded the Spaniards and Indians, then a European national identity that excluded its British roots, and finally a distinctively 'American' identity that excluded its European roots” (Kubal 2008: 24).

Such a complex social process has been internalized in language throughout the last three centuries in many ways and through many communication modes. As far as the recent perspective is concerned, some examples from the signs displayed on Columbus Day in the last two years are reported in Table 1.

Table 1. Signs displayed on Columbus Day (2015-2016)

\begin{tabular}{|l|l|}
\hline Signs & Source and date \\
\hline (1) Colonialism is indigenous genocide & Boston Globe, \\
(2) Columbus was a murderer not a hero & October 12, 2015 \\
\hline (3) Don't celebrate genocide / Abolish Columbus Day / & Native News Online.net, \\
Columbus was a murderer & October 13, 2015 \\
(4) Indigenous People's Day & \\
(5) Don't support genocide & \\
(6) Genocide is nothing to celebrate & \\
(7) Columbus was a rapist & \\
\hline
\end{tabular}




\begin{tabular}{|l|l|}
\hline Signs & Source and date \\
\hline (8) Illegal immigration / Europeans as illegals since 1492 & NPR, October 7, 2016 \\
\hline (9) Columbus was no hero & CNN, October 10, 2016 \\
\hline (10) Chumash land is where you stand & Daily Nexus, \\
(11) Stop genocide racism and imperialism & University of California at Santa \\
(12) Respect existence or expect resistance & Barbara, \\
(13) Columbus didn't discover America, he invaded it & October 10, 2016 \\
\hline (14) 50,000 Tainos committed mass suicide to escape & Oberline News Tribune, October \\
Christopher Columbus & 11,2016 \\
(15) Columbus murderer & \\
(16) Columbus: Failure as a navigator / Failure as a gover- \\
nor / Taken home in chains / Let's honor him! (underlined \\
in the original) & \\
\hline (17) No more genocide & \\
(18) Columbus criminal & Los Angeles Times, \\
\hline
\end{tabular}

1 Slashes mark a new line in the poster.

The views voiced by the demonstrators on their signs are mainly conveyed through overtly evaluative lexical choices that - according to the Appraisal System (Martin and White 2005) - can be placed within the subregion of attitude labelled as judgement, which encompasses both social esteem and social sanction. Tellingly, most items are related to propriety, one of the two subcategories of social sanction that covers the realm of ethics (the other one being veracity, i.e. how truthful one is). The most frequent word in the sample selection collected, genocide, with its dreadful connotations stemming from its first use in relation to the Holocaust perpetrated on European Jews in the twentieth century, unquestionably provides a totally different framework for Columbus's name, placing it in the semantic field of "crime" along with murderer, criminal and rapist. An example of judgment as social esteem is provided in (16), in which failure not only expresses disdain for Columbus's deeds as a governor, but also undermines his ability as a sailor, which is at the core of Morison's (1942) well known biography of Columbus and has seldom been debated even among his detractors. The stance taken is further emphasized by the irony displayed in the closing line of the sign: by being in sharp contrast with the picture just drawn, the sentence "Let's honor him!" obviously implies that he is not worth honoring given his failures. However, evaluation can also be invoked as in (14); even in absence of evaluative language, the fact reported in the bare statement is itself enough to trigger negative evaluation. In a similar fashion, as far as the bare statements in (10) and (14) are concerned, these are not to be considered factual or objective (Martin and White 2005: 99), but in terms of their dialogistic functionality. In other words, what is relevant in the light of appraisal theory is that they do not overtly make reference to other voices; they are presented as having no dialogistic alternatives that need to be recognized. Thus, what is stated cannot but be agreed upon, implying a backdrop of shared views. A further example can be found in (4), where just stating how the holiday has been/has to be renamed is enough to 
assert whose identity has to be foregrounded. Another point is made in (13), where the discovery is reworded as invasion, one of the issues raised by some revisionist books (Zinn 1980, Sale 1990) that, in contrast with the admired, benevolent tones drawing a heroic Columbus in the past (Irving 1828), lay emphasis on the darker sides of the explorer's journeys.

Although the holiday name had more to do with the ethnic meaning of Columbus's name than with the trope of discovery, current narratives point to 1492, that is, to the history that has to be retold to meet present needs. On the linguistic side, both the renaming of the holiday and the negative evaluation conveyed by the texts analyzed contribute to legitimizing the desecration of a once venerated symbol. As such, he is undoubtedly no longer worth celebrating. Both the interpersonal style and the rhetorical strategies employed in the texts analyzed leave no room for alternative viewpoints: other traditions take shape and nurture Indigenous People's Day, as the holiday has been renamed in about thirty cities in the last twenty-five years.

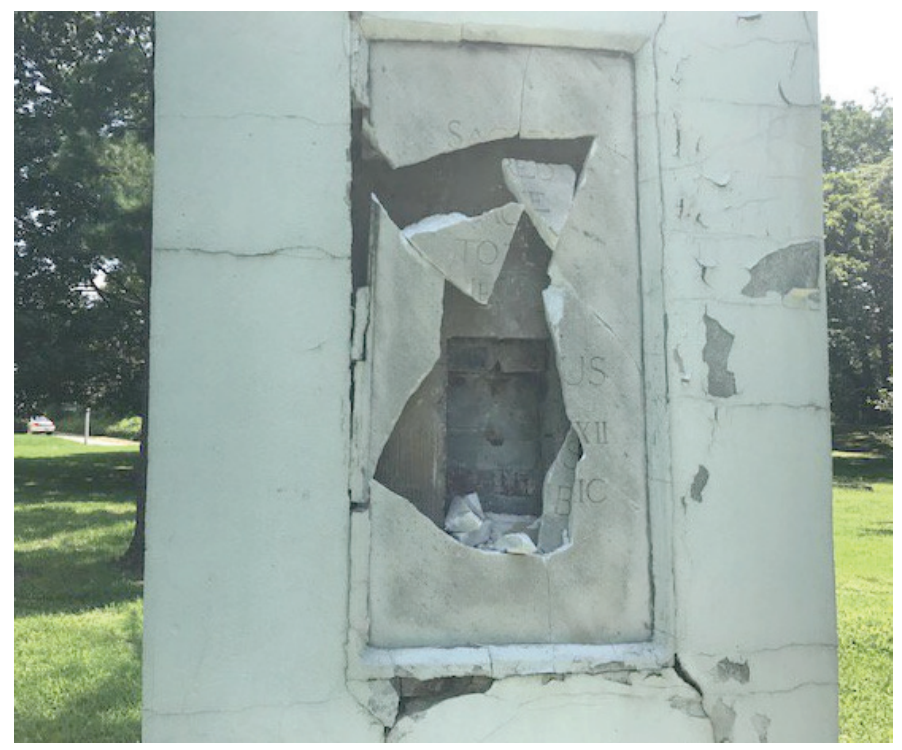

Figure 3. Columbus Obelisk, Herring Park, Baltimore

(The Baltimore Sun, August 21, 2017)

Like the social meaning attached to names, the meaning attached to monuments and memorials is equally crucial and varies depending on the different ways of remembering the past and on the narratives that these entail. A case in point is represented by the controversies that have recently emerged over confederate monuments, whereby they have been removed, covered up or vandalized. And not surprisingly, some of those honoring Columbus have shared a similar destiny. For example, the first permanent monument erected to the then hero, the above-mentioned obelisk in Baltimore, has 
recently been vandalized by protesters who smashed a hole in the monument, rendering its inscription, "Sacred to the Memory of Chris. Columbus Oct. XII MDCC VIIIC”, unreadable (Figure 3).

Vandalized monuments may then be thought of as the visual, material counterpart of the language analyzed above, moments of a controversial social process embedded in competing collective memories that are created and nurtured by the need for identity and sense of belonging of a given community but also by scholarly research. As McNeill (1990) notes reviewing Sale's revisionist work, when detractors and advocates of Columbus select from "the often cloudy record of Columbus's actual motives and deeds what suits the researcher's 20th-century purposes", they may end up presenting a "sort of history [that] caricatures the complexity of human reality by turning Columbus into either a bloody ogre or a plaster saint, as the case may be”.

\section{Concluding remarks}

This paper has sought to trace the ways in which Columbus's name has permeated American collective memory for more than three hundred years now, reverberating with different meanings at each centenary, sometimes as a result of new information available, quite often, though, because of changes in the lenses through which Columbus has been viewed. He started to gain mythical status after the Declaration of Independence in 1776, when he was seen as an intrepid explorer setting out into the unknown, in a sense, like the new citizens of the United States. Then in 1892, when discovery and progress were coupled together to herald American industrial expansion, he was venerated as a symbol of progress. Also, after being "appointed" the first immigrant, he was invested with the task to mitigate the conflicts resulting from the massive immigration of the second half of the nineteenth century. Finally, about twenty years before the latest centenary in 1992, the mythical, sacred Columbus was deemed worth celebrating with a federal holiday named after him. However, the Quincentenary marked the official beginning of the desecration of Columbus's name with the first renaming of Columbus Day as Indigenous People's Day in Berkley. Columbus's name was drawing different identity boundaries, so he could no longer sit with Tammany smoking a peace pipe, as he had done during a special Columbus commemoration organized by the Tammany Society or Columbus Order in 1811.

As a result of changing social settings, perceptions change, and so does our understanding of the past, especially if we consider that " $[\mathrm{t}]$ he core meaning of any individual or group identity, namely a sense of sameness over time and space, is sustained by remembering" (Gillis 1994: 3); hence, there is no answer to whether Columbus was a saint or a criminal (Fernández-Armesto 1992). Rather, the "plaster saint" and the "bloody ogre" have been created in the space of American collective memory to address a wide range of cultural and political needs across time, more like a fabric that has woven self-confidence, hopes and aspirations, faith in progress, the need of this or that community for a more just society. With all the meanings that it has taken in time, no doubt Columbus's name testifies to the power of names in inventing 
traditions, demonstrating that a name may be consecrated or desecrated depending on whose history it is writing. As "[e]very generation creates the Columbus it needs" (Wilford 1991: 1), different narratives of Columbus's arrival to the Americas have been produced. Also, the very word discovery, which has defined that epochal event for centuries, is at present often avoided in favor of the more careful encounter, enterprise and exchange (Bushman 1992: 9), safer linguistic choices for a debated enterprise.

Accordingly, as one of the "moments" of the social process, language provides further insights into the ways in which collective memory is reconfigured. As discussed above, lexical and rhetorical strategies in the texts collected relegate Columbus's name to the area of negative social sanction, taking for granted the absence of alternative viewpoints. Hence, when considering the social power of names from a critical perspective, a focus on people's actual reactions and ways of positioning may contribute to name studies, and especially so when it comes to controversial cases. In addition, since public holidays act as environments of memory, as they change, the language related to them changes as well. Erasing Columbus's name is like erasing the enactment of his landing, leaving room for new wor(l)ds to be written.

\section{References}

Alderman, D. H. 2008. Place, Naming and the Interpretation of Cultural Landscapes. In The Ashgate Research Companion to Heritage and Identity, B. Graham and P. Howard (eds.), 195213. Aldershot UK: Ashgate Publishing Limited.

Anderson, B. 1991. Imagined Communities, 2nd edition. London: Verso.

Armada, B.J. 1998. Memorial Agon: An Interpretive Tour of the National Civil Rights Museum. The Southern Communication Journal 63 (3): 235-243.

Azaryahu, M. 1996. The Power of Commemorative Street Names. Environment and Planning D: Society and Space 14 (3): 311-330.

Bushman, C. L. 1992. America Discovers Columbus: How an Italian Explorer Became an American Hero. Hanover NH: University Press of New England.

Caiazzo, L. 2014. Mumbai is not Bombay: Naming and Evaluation. Paper presented at the International Conference "Names and Naming in the Postcolonial English-speaking World", 26-27 June 2014, Università della Calabria, Rende (Cosenza) Italy.

Caiazzo, L. in press. Mumbai is not Bombay: Bloggers' Views. In Names and Naming in the Postcolonial English-speaking World, Mirko Casagranda (ed.). Trento: Tangram Edizioni Scientifiche.

Dennis, M. 2002a. The Eighteenth-Century Discovery of Columbus. The Columbian Tercentenary and the Creation of American National Identity. In Riot and Revelry in Early America, W. A. Pencak, S. Newman and M. Dennis (eds.), 206-228. PA: Penn State University Press.

Dennis, M. 2002b. Red, White, and Blue Letter Days: An American Calendar. Ithaca NY: Cornell University Press.

Felecan, O. And A. Bugheșiu (eds.). 2013. Onomastics in Contemporary Public Space. Newcastle upon Tyne: Cambridge Scholars Publishing

Fernández-Armesto, F. 1992. Columbus - Hero or Villain? History Today 42 (5). http://www. historytoday.com/felipe-armesto/columbus-hero-or-villain (accessed July 25, 2017). 
Firth, J. R. 1957. Papers in Linguistics 1934-1951. London: Oxford University Press.

Gillis, J. H. (ed.) 1994. Commemorations: The Politics of National Identity. Princeton NJ: Princeton University Press.

Harvey, D. 1996. Justice, Nature \& the Geography of Difference. Oxford: Blackwell Publishing.

Hobsbawm, E. 1983. Mass-Producing Traditions: Europe, 1870-1014. In The Invention of Tradition, E. Hobsbawm and T. Ranger (eds.), 263-307. Cambridge: Cambridge University Press.

Irving, W. 2008 [1828]. A History of the Life and Voyages of Christopher Columbus. Hertfordshire: Wordsworth Editions Limited.

Kammen, M. 1993. Mystic Chords of Memory: The Transformation of Tradition in American Culture. New York: Vintage Books.

Kubal, T. 2008. Cultural Movements and Collective Memory. Christopher Columbus and the Rewriting of the National Origin Myth. New York: Palgrave Macmillan.

Martin, J. R. and P. R. White. 2005. The Language of Evaluation: Appraisal in English. New York: Palgrave/Macmillan.

McNeill, W. H. 1990. Debunking Columbus. The New York Times, October 7. http://www. nytimes.com/1990/10/07/books/debunking-columbus.html (accessed July 15, 2017).

Morison, S. E. 1942. Admiral of the Ocean Sea - A Life of Christopher Columbus. Boston: Little, Brown and Company.

Roach, J. 1996. Cities of the Dead: Circum-Atlantic Performance. New York: Columbia University Press.

Sale, K. 1992 [1990]. The Conquest of Paradise. Christopher Columbus and the Columbian Legacy. Basingstoke UK: Macmillan Paperback.

Schlereth, T. J. 1992. Columbia, Columbus, and Columbianism. The Journal of American History, Discovering America: A Special Issue 79 (3): 937-968.

Vuolteenaho, J. and L. D. Berg. 2009. Towards Critical Toponymies. In Critical Toponymies. The Contested Politics of Place Naming, D. B. Lawrence and J. Vuolteenaho (eds.), 1-18. Burlington VT: Ashgate.

Wilford, J. N. 1991. Columbus and the Labyrinth of History. The Wilson Quarterly 15 (2): 66-86. Williams, R. 1997. Marxisism and Literature. Oxford: Oxford University Press.

Zinn, H. 1980. A People's History of the United States. Harlow UK: Longman. 